No appreciable reaction took place when $\mathrm{NaF}$, in place of KF, was heated with 1:2:4-chlorodinitrobenzene employing the conditions given above.

\section{Physiological examination}

(1) A batch of 23 rabbits, rats, guinea-pigs and mice were exposed to a $\mathrm{Ct}^{*}$ of $5000 \mathrm{mg}$. $\mathrm{min} . / \mathrm{m}^{3}$ in a $1.87 \mathrm{~m}^{3}$ static chamber. The material was sprayed in ether $(25 \mathrm{ml}$.). During exposure the animals suffered from irritant action, but recovered after being removed from the chamber. At the end of a week there were no deaths. The batch was then re-exposed to the same Ct. The irritation seemed more intense and all four guinea-pigs died in $48 \mathrm{hr}$. The postmortem examination showed changes typical of those caused by a lung irritant.

(2) Subcutaneous injection into mice, using propylene glycol as solvent: $100 \mathrm{mg} . / \mathrm{kg}$. killed $1 / 6$.

(3) Vesicancy on human skin. Benzene solutions of 1:2:4-fluorodinitrobenzene $\left(F^{\prime}\right)$ were dropped on to the right arms of two subjects, and similar solutions of 1:2:4-chlorodinitrobenzene $(\mathrm{Cl})$ were dropped on to the left arm. There was free evaporation.

$5 \mathrm{mg}$. drops of $1 \%$ solution (i.e. $50 \mu \mathrm{g}$.) had no effect within 4 days. $5 \mathrm{mg}$. drops of $10 \%$ solutions (i.e. $500 \mu \mathrm{g}$.) produced considerable irritation as follows:

* Ct is the dose expressed as concentration $\mathrm{mg} \cdot / \mathrm{m} \cdot{ }^{3} \times$ time of exposure (min.).
Subject 1. F patch. Smarting and swelling in $7 \mathrm{hr}$., blister without surrounding erythema in $36 \mathrm{hr}$. No change when blister was pricked on 3rd day. Scar almost healed by 9th day. $C l$ patch. During the first 9 days there was no more than a red weal. By the 12 th day there was irritation and swelling which subsided on the 15th day.

Subject 2. F patch. Immediate smarting and swelling which persisted for 1 day, and subsided the next day without a blister. After 3 days the skin broke down with formation of pus and scabs. After 8 days only a scar remained. $C l$ patch. Slight redness during first 8 days. Swelling on 9th day and weal rash of vesicles on 10th day. The spots oozed freely on the 14th day. Recovery on 20th day.

\section{SUMMARY}

1. A convenient method of preparing 1:2:4fluorodinitrobenzene is described.

2. The compound is relatively non-toxic in comparison with the highly toxic fluoroacetates. - It produces, however, a slight vesication on human skin.

Our thanks are due to the Director General of Scientific Research (Defence) for permission to publish the above and to Mr K. J. Carpenter who carried out the physiological examination of the action of the compound on animals.

\title{
REFERENCES
}

Chapman, N. B., Heap, R. \& Saunders, B. C. (1947). To be published.

Gottlieb, H. B. (1936). J. Amer. chem. Soc. 58, 532.

Holleman, A. F. \& Beekmann, J. W. (1904). Rec. Trav. chim. Pays-Bas, 23, 240.

McCombie, H. \& Saunders, B. C. (1941). Reports to Ministry of Supply on Fluorophosphonates and Fluoroacetates, 1941, onwards.*
McCombie, H. \& Saunders, B. C. (1946a). Nature, Lond., 157, 287.

McCombie, H. \& Saunders, B. C. (1946b). Nature, Lond., 157, 776.

McCombie, H. \& Saunders, B. C. (1946c). Nature, Lond., 158, 382.

Sanger, F. (1945). Biochem. J. 39, 507.

* Information available on application to Ministry of Supply, London.

\section{The Utilization of Nicotinamide Derivatives and Related Compounds by Mammals, Insects and Bacteria}

\author{
By P. ELLINGER, G. FRAENKEL AND M. M. ABDEL KADER (Member of the \\ Egyptian Ministry of Education Mission), Lister Institute of Preventive Medicine, London, \\ and the Biological Field Station, Imperial College of Science and Technology, Slough, Bucks
}

(Received 15 January 1947)

This investigation was prompted by the desire to find an antipellagra drug of the efficiency of nicotinamide, but of a greater lasting effect similar to that of nicotindiethylamide (nikethamide) (Ellinger \& Coulson, 1944). For this purpose a number of nicotinamide derivatives in which one or both hydrogen atoms of the amide were replaced by alkyl, cyclo- hexyl, or aryl groups were tested for their ability to form nicotinamide and to exhibit antipellagra activity. This aim was not reached, but the investigation gave results which are of interest, since they give some information about the relation of chemical constitution to pharmacological action and about the ability of widely different species to transform 
nicotinamide derivatives and related compounds into nicotinamide or nicotinic acid which are essential to all of them.

Anti black-tongue activity of a large number of such compounds has been studied by Woolley, Strong, Madden \& Elvehjem (1938); SubbaRow, Dann \& Meilman (1938); Strong, Madden \& Elvehjem (1938); SubbaRow \& Dann (1938); Waisman, Mickleson, McKibbin \& Elvehjem (1940); Smith, Margolis \& Margolis (1940) and Teply, Krehl \& Elvehjem (1945). These authors found the following to be active: nicotinic acid, nicotinamide, nicotinmethylamide, nicotindiethylamide, nicotinamide glucosidoiodide, nicotinuric acid and to a lesser degree $\beta$-picoline, whilst trigonelline, nicotinamide methochloride, pyridine, pyridine-3-sulphonic acid, 6-methylnicotinic acid, 3-acetylpyridine, 3-aminopyridine, quinolinic acid, picolinic acid, isonicotinic acid, hexahydronicotinic acid, nicotinonitrile, pyrazine mono- and 2:3-dicarboxylic acids, and thiazole-5carboxylic acid were found to be inactive in canine blacktongue. Nicotinuric acid was found inactive by Dann \& Handler (1941) and nicotinamide methochloride active by Najjar, Hammond, English, Wooden \& Deal (1944).

Antipellagra activity has been mainly studied by Spies and his co-workers (Spies, Bean \& Stone, 1938; Spies, Grant \& Huff, 1938; Vilter \& Spies, 1939; Vilter, Bean \& Spies, 1938; Bills, McDonald \& Spies, 1939), and by Smith et al. (1940). The results are less definite than those obtained for black tongue activity. It is certain, however, that nicotinic acid, nicotinamide, nicotinethylamide and -diethylamide, ethyl nicotinate, quinolinic acid, and pyrazine monoand 2:3-dicarboxylic acids are active against pellagra. $\alpha$-Picoline, trigonelline, and 3-aminopyridine are inactive, whilst $\beta$-picoline, 2:6-dimethylpyridine-3:5-dicarboxylic acid, and pyridine-3:5-dicarboxylic acid are of doubtful activity.

Nicotinamide methochloride has been found to be formed in the mammalian body after administration of nicotinic acid, nicotinamide or nicotindiethylamide (Najjar \& Holt, 1941; Ellinger \& Coulson, 1944). The former authors found no increased nicotinamide methochloride elimination after administration of trigonelline, 2:6-dimethylpyridine-3:5-dicarboxylic acid, quinolinic acid, pyridine-3:5-dicarboxylic acid and pyrazine mono- and 2:3dicarboxylic acids.

Very little is known of the pharmacological and toxicological effects of nicotinamide and related compounds in mammals. The lethal doses of nicotinic acid, nicotinamide, nicotindiethylamide, pyridine, pyridine methochloride, trigonelline, nicotinamide methochloride, and nicotindiethylamide methochloride have been studied for the rat, mouse, and guinea-pig by Chen, Rose \& Robbins (1938), Unna (1939) and Brazda \& Coulson (1946). Whilst Ackermann (1913) failed to observe any toxic effect of nicotinic acid 'in medium-sized dogs after ingestion of $9 \mathrm{~g}$. during 5 days', Chen et al. (1938) report lesions of the intestinal mucosa and central nervous system in dogs after large doses of nicotinic acid.

The need of insects for nicotinic acid seems to be general. This has been demonstrated, e.g. for Droso- phila (Tatum, 1939, 1941), mosquitoes (SubbaRow \& Trager, 1940), Galleria (Rubinshtein \& Shekun, 1941), Tribolium and many other beetles and moths (Fraenkel \& Blewett $(1943 b, 1946 a, b)$, Blewett \& Fraenkel, 1944). The effects of nicotinamide and other derivatives of nicotinic acid on insects have, however, never been investigated.

The utilization of a number of compounds related to nicotinic acid by various bacteria (Staphylococcus aureus, Proteus vulgaris, dysentery bacilli, Lactobacillus arabinosus) has been studied by Landy (1938), Fildes (1938), Lwoff (1938), Lwoff \& Querido (1939), Dorfman, Koser, Reames, Swingle \& Saunders (1939), Pelczar \& Porter (1940), Elvehjem \& Teply (1943) and v. Euler, Högberg, Karrer, Salomon \& Ruckstuhl (1944). Of the compounds tested, nicotinic acid, nicotinamide, methyl, ethyl, propyl and butyl nicotinate, and nicotinuric acid could be utilized by all bacteria examined, nicotinethylamide and -diethylamide and quinolinic acid were reported to be utilized by Proteus and dysentery bacilli. $\beta$-Picoline, nicotinonitrile, pyridine-3-sulphonic acid only by Proteus, tetrahydro-, and hexahydronicotinic acid (nipecotic acid) by Staphylococcus aureus and Proteus, and picolinic acid and isonicotinic acid by none of the bacteria. Hexahydronicotinic acid had only very little activity in promoting growth of Lactobacillus arabinosus (Teply et al. 1945). Najjar, Scott \& Holt (1943) considered nicotinamide methochloride a powerful growth promoter for Escherichia coli and Haemophilus influenzae.

In the present investigation a number of new and known nicotinamide derivatives have been examined for their general pharmacological action and toxicity on mice or rats. Their ability to form nicotinamide and nicotinamide methochloride and the speed of elimination was also investigated. Attempts were also made to study the mechanism of the breakdown of the substances in the body. The utilization of nicotinamide derivatives by insects was tested by their effects upon growth and development of larvae of Tribolium confusum, and utilization by bacteria by effects on growth and acid formation of Lactobacillus arabinosus, Proteus and dysentery strains. The formation of nicotinamide methochloride from nicotinamide by Tenebrio larvae and by some Proteus strains has been investigated.

\section{METHODS}

The drugs used in the experiment are shown in Table 1. The purity of hitherto unknown substances made by Bayer was checked by analysis. Hydrochlorides were dissolved in water, bases in equivalent amounts of dilute $\mathrm{HCl}$ and acids in equivalent amounts of dilute $\mathrm{NaOH}$. Nikethamide was obtained as $25 \%$ aqueous solution.

Experiments on mammals. General pharmacological action and toxicity were observed in mice, hooded rats (Lister stock), and albino rats (own stock of P.E.). The drugs were administered in 5-20\% solution by intraperitoneal injections to mice of 20-30 g. and rats of 150-300 g. To find the $L D_{50}$ the region was first explored with doses differing from each other by $50 \%$ and, when a suitable 
order of dose had been established, groups of 4 mice or rats (2, if material was limited) were given doses differing by $10 \%$ from each other; at the same time the general pharmacological effect of the various drugs was studied.

To investigate the increased urinary elimination of nicotinamide methochloride after administration of the various drugs, rats of $200-300 \mathrm{~g}$. were kept in metabolism cages, $24 \mathrm{hr}$. urine samples were collected and their nicotinamide methochloride content estimated by the method of Coulson, Ellinger \& Holden (1944). During this period the rats were on the following diet: $10 \mathrm{~g}$. of a mixture composed of $4 \cdot 0 \mathrm{~g}$. of a grain mixture, $3.5 \mathrm{~g}$. of extracted liver (British Drug Houses), $1.0 \mathrm{~g}$. of wheat germ, $0.3 \mathrm{~g}$. of dried yeast, $0.5 \mathrm{~g}$. of McCollum's salt mixture, no. 185 (McCollum, Simmonds \& Pitz, 1917), $0.6 \mathrm{~g}$. of maize oil and $0.1 \mathrm{~g}$. of cod-liver oil, $13 \mathrm{~g}$. of bread and $1.5 \mathrm{~g}$. of dried milk (Glaxo) in $30 \mathrm{ml}$. of water. The content of nicotinamide in the diet, estimated chemically (Ellinger \& Abdel Kader, 1947), was $1.0 \mathrm{mg}$. and of nicotinic acid $0.8 \mathrm{mg}$. A number of $24 \mathrm{hr}$. urine samples (3-5) were examined for nicotinamide methochloride (N.M.), then nicotinamide (20 mg.) was injected intraperitoneally and the response to this dose examined by determinations continued until the predosing level was regained. From the extra output (extra N.M.) in mg. the response $x$, was calculated by the following formula:

$$
x=\frac{\text { mg. extra N.M. }}{\text { mg. } D \text { ingested }} \times 100 \times \frac{\text { mol. wt. } D}{\text { mol. wt. N.M. }},
$$

where $D$ is the compound ingested. This gives the percentage of the nicotinamide dose which appears in its methylated form in the urine. After an interval of 7 days one of the other drugs was injected in equimolar dose to the rats calibrated with nicotinamide and the response was calculated in a similar manner. All drugs examined were tested in duplicate at least.

In order to gain further information on the transformation of the substituted nicotinamide compounds into nicotinamide methochloride, the following experiments were carried out similarly to those described by Ellinger (1946). Rats were stunned and bled, the various organs were removed, pieces were cut off and weighed in wet state, then cut into slices of $0 \cdot 2-0 \cdot 4 \mathrm{~mm}$. thickness. These were suspended in $10 \mathrm{ml}$. of modified Ringer solution (Krebs \& Henseleit, 1932), aerated with an $\mathrm{O}_{2}-\mathrm{CO}_{2}$ mixture, and $10 \mu \mathrm{g} . / \mathrm{ml}$. of the various substituted nicotinamide derivatives were added. The tubes contained either liver alone, or slices of one of the following organs alone or with liver; kidney, brain, spleen, skeletal muscle, heart muscle, pancreas or intestinal mucous membrane. The mixture was agitated at $37^{\circ}$ for $2-3 \mathrm{hr}$. After cooling to room temperature, the supernatant liquid was separated from the tissue, protein was removed with trichloroacetic acid and by heating to $70-80^{\circ}$ followed by centrifuging. Nicotinamide methochloride was estimated in the supernatant liquid by the method of Coulson et al. (1944).

Experiments on insects. The experiments were carried out on larvae of Tribolium confusum by the method of Fraenkel $\&$ Blewett $(1943 a, b)$. The nicotinic acid-free diet consisted of $50 \mathrm{~g}$. of acid-extracted casein (Glaxo), $50 \mathrm{~g}$. of anhydrous glucose, $5 \mathrm{~g}$. of the water-insoluble fraction of yeast (exhaustively extracted with hot water), $1 \mathrm{~g}$. of cholesterol, $2 \mathrm{~g}$. of McCollum's salt mixture no. 185 (McCollum et al. 1917) and $10 \mathrm{ml}$. of water. The following vitamins of the $B$ complex were added ( $\mu$ g./g. dry diet): aneurin, 25 ; ribo- flavine, 25; pyridoxin, 12.5; pantothenic acid, 25; choline chloride, 250; inositol, 250. All tests were performed at $25^{\circ}$ and $70 \%$ relative humidity. The compounds to be tested were added to the diet in various quantities and their effect compared with that of nicotinic acid and nicotinamide. The growth of the larvae, the number of pupae, and the average time of pupation formed the basis for a quantitative comparison.

To study the question whether nicotinamide methochloride is formed by insects, $60 \mathrm{~g}$. of larvae of Tenebrio grown in white flour (75\% extraction) with the addition of $5 \%$ yeast were killed, frozen, ground with sand, dried to about $20 \mathrm{~g}$. weight, extracted with $0 \cdot 1 \mathrm{~N}-\mathrm{HCl}$, and filtered. The filtrate $(150 \mathrm{ml}$.) was dialyzed three times for 2 days against $200 \mathrm{ml}$. of distilled water each time. The dialysates were combined, reduced to $50 \mathrm{ml}$. by evaporation in vacuo and then examined for nicotinamide methochloride by the method of Coulson et al. (1944). ' $F_{2}$ ' was tested for by reactions with $12 \mathrm{~N}-\mathrm{KOH}, \mathrm{K}_{3} \mathrm{Fe}(\mathrm{CN})_{6}$ and alkaline acetone (Najjar et al. 1943).

Experiments on bacteria. The various drugs were tested on the following bacteria which require nicotinic acid or nicotinamide for growth: Lactobacillus arabinosus, obtained from Dr T. F. Macrae; Proteus vulgaris 401, 3156, 5887, from the National Collection of Type Cultures; Proteus morganii, isolated from rat faeces; Proteus X 13 syriac, from Dr A. Lwoff, Paris; Shigella sonnei 2941; Flexner 4832; and Shiga 4837, all from the National Collection of Type Cultures. In addition, the effect of nicotinamide methochloride on growth and acid formation of $E s c h$. coli was studied in an ammonium-glucose medium on five strains isolated from human and rat faeces. The medium used for Lactobacillus arabinosus was that described by Barton-Wright (1944); for the other bacteria a medium of the following composition was used; $\mathrm{K}_{2} \mathrm{HPO}_{4}, 2.25 \mathrm{~g}$.; $\mathrm{NH}_{4} \mathrm{Cl}, 0 \cdot 25 \mathrm{~g} . ;\left(\mathrm{NH}_{4}\right)_{2} \mathrm{SO}_{4}, 0 \cdot 25 \mathrm{~g} . ; \mathrm{FeSO}_{4} \cdot\left(\mathrm{NH}_{4}\right)_{2} \mathrm{SO}_{4} \cdot 6 \mathrm{H}_{2} \mathrm{O}$, $0.01 \mathrm{~g} . ; \mathrm{MgSO}_{4} \cdot 7 \mathrm{H}_{2} \mathrm{O}, 0.01 \mathrm{~g}$; ; the mixture was made up with distilled water to $250 \mathrm{ml}$. The $\mathrm{pH}$ was adjusted to 7.6 with $\mathrm{N}-\mathrm{NaOH}$. The solution was boiled and filtered while hot through a no. 50 filter. The volume was brought to $400 \mathrm{ml}$. after cooling and the solution was then autoclaved; $0.25 \mathrm{ml}$. of sterile $0.5 \mathrm{M}$-glucose solution was added to $8 \mathrm{ml}$. of the salt solution. After adding the sterile test solutions of the nicotinamide derivatives the volume was made up to $10 \mathrm{ml}$. with sterile water. Two drops of a thin emulsion of the inoculum were added to the medium. After 2-3 days of incubation at $37^{\circ}$, growth was measured by visual estimation of the turbidity and by determination of the acid produced using $0 \cdot 1 \mathrm{~N}-\mathrm{NaOH}$ and bromothymol blue as internal indicator. In each experiment blanks were done without inoculum and without the addition of nicotinamide compounds, and the values of the latter were deducted from the experimental values. Tests with nicotinic acid and nicotinamide at different concentrations were carried out as standards for comparison. The compounds to be tested were used in at least two concentrations. In each case the efficiency of the tested compound in forming acid was compared with that of nicotinic acid.

To examine for possible formation of nicotinamide methochloride from nicotinamide or nicotinic acid, Proteus vulgaris 3156 was incubated for $48 \mathrm{hr}$. both aerobically and anaerobically in a casein hydrolysate medium (BartonWright, 1944) containing $1 \mu \mathrm{g} . / \mathrm{ml}$. nicotinamide or nicotinic acid. Samples were autoclaved and examined for 
nicotinamide methochloride. The remainder was centrifuged, and the supernatant liquid also examined for nicotinamide methochloride by the method of Coulson et al. (1944). Controls were done by incubating the medium alone and by estimating the nicotinamide methochloride content immediately after inoculation without incubation.

\section{RESULTS}

Pharmacological action. The pharmacological offect of all the compounds tested was qualitatively almost identical, viz. an action on the central nervous system, excitation with convulsions, narcosis, paralysis of the respiratory and the heat regulation centres. In some cases, nos. 12-16, the body temperature of the animals was little above that of their surroundings and changed with it, if the poisoning lasted for more than $24 \mathrm{hr}$.; none of these animals recovered. With some of the compounds $(1,4,6,7,18)$ the exciting action predominated; mice developed a 'morphia tail' and jumped like kangaroos; both mice and rats were very restless, convulsions developed and frequently the animals died as a result of one of these. With most of the other compounds the narcotic action was predominant, the animals fell asleep, respiration deteriorated and after a few convulsions death super-

Table 1. Toxicity and utilization of nicotinic acid, nicotinamide and related compounds in mice and rats

(The values given in the column for nicotinamide methochloride response are averages of four experiments; the limiting values are given in brackets.)

\begin{tabular}{|c|c|c|c|c|c|c|c|}
\hline D. & \multirow[b]{3}{*}{ Name of compound } & \multicolumn{4}{|c|}{ Toxicity (LD50) } & \multirow{3}{*}{$\begin{array}{c}\text { Nicotinamide } \\
\text { metho- } \\
\text { chloride } \\
\text { response* } \\
\text { (\% of } \\
\text { theoretical) }\end{array}$} & \multirow{3}{*}{$\begin{array}{c}\text { Period of } \\
\text { elimination } \\
\text { (hr.) }\end{array}$} \\
\hline \multirow[b]{2}{*}{ No. } & & $(a)$ & Mouse & (b) & Rat. & & \\
\hline & & (g./kg.) & (mmol./kg.) & (g./kg.) & (mmol./kg.) & & \\
\hline 1 & Nicotinic acid & $4 \cdot 5$ & 36.55 & $3 \cdot 75$ & $30 \cdot 90$ & $\begin{array}{c}11 \cdot 8 \\
(7 \cdot 9-13 \cdot 3)\end{array}$ & 48 \\
\hline 4 & Nicotinamide & $1 \cdot 75$ & $14 \cdot 32$ & $1 \cdot 50$ & $12 \cdot 28$ & $\begin{array}{c}22 \cdot 7 \\
(18 \cdot 2-27 \cdot 8)\end{array}$ & 48 \\
\hline $\mathbf{5}$ & Nicotinethylamide $\uparrow$ & $0 \cdot 65$ & $4 \cdot 34$ & $0 \cdot 52$ & $3 \cdot 47$ & $\begin{array}{c}17 \cdot 2 \\
(14 \cdot 3-19 \cdot 1)\end{array}$ & 48 \\
\hline 6 & Nicotindiethylamide & 0.42 & $2 \cdot 36$ & 0.45 & $2 \cdot 55$ & $\begin{array}{c}16 \cdot 8 \\
(14 \cdot 7-18 \cdot 2)\end{array}$ & 72 \\
\hline 7 & Nicotinallylamide & $0 \cdot 55$ & $3 \cdot 40$ & $0 \cdot 45$ & $2 \cdot 78$ & $\begin{array}{c}15 \cdot 7 \\
(13 \cdot 6-16 \cdot 9)\end{array}$ & 48 \\
\hline 8 & Nicotincyclohexylamide & 0.35 & $1 \cdot 71$ & $0 \cdot 45$ & 1.99 & 0 & - \\
\hline 9 & $\begin{array}{l}\text { Nicotin-(2'-methylcyclohexyl)- } \\
\text { amide }\end{array}$ & $0 \cdot 175$ & $0 \cdot 80$ & $0 \cdot 20$ & 0.91 & 0 & - \\
\hline 10 & $\begin{array}{l}\text { Nicotin-(3'-methylcyclohexyl)- } \\
\text { amide }\end{array}$ & $0 \cdot 12$ & 0.51 & $0 \cdot 13$ & $0 \cdot 60$ & 0 & - \\
\hline 11 & $\begin{array}{l}\text { Nicotin-(4'-methylcyclohexyl)- } \\
\text { amide }\end{array}$ & $0 \cdot 18$ & $0 \cdot 83$ & $0 \cdot 20$ & 0.91 & 0 & - \\
\hline 12 & Nicotinphenylamide & 0.375 & 1.90 & $0 \cdot 40$ & $2 \cdot 02$ & $\begin{array}{c}6 \cdot 5 \\
(4 \cdot 7-8 \cdot 3)\end{array}$ & 72 \\
\hline 13 & Nicotindiphenylamide & $0 \cdot 07$ & $0 \cdot 26$ & $0 \cdot 05$ & $0 \cdot 18$ & 0 & - \\
\hline 14 & $\begin{array}{l}\text { Nicotin-(4'-methoxyphenyl)- } \\
\text { amide }\end{array}$ & 0.35 & $1 \cdot 53$ & $0 \cdot 40$ & $1 \cdot 76$ & $\begin{array}{c}6 \cdot 2 \\
(3 \cdot 8-7 \cdot 6)\end{array}$ & 72 \\
\hline 15 & Nicotinbenzylamide & 0.08 & $0 \cdot 38$ & $0 \cdot 07$ & $0 \cdot 34$ & $\begin{array}{c}5 \cdot 8 \\
(4 \cdot 2-6 \cdot 9)\end{array}$ & 72 \\
\hline 16 & Nicotindibenzylamide & $0 \cdot 035$ & $0 \cdot 12$ & $0 \cdot 035$ & $0 \cdot 12$ & 0 & 一 \\
\hline 17 & Trigonelline hydrochloride & $4 \cdot 80$ & $27 \cdot 68$ & $5 \cdot 20$ & $30 \cdot 00$ & 0 & 一 \\
\hline 18 & Nicotinamide methochloride & 0.48 & $2 \cdot 78$ & 0.95 & $5 \cdot 50$ & $\begin{array}{c}62 \cdot 7 \\
(56 \cdot 2-68 \cdot 3)\end{array}$ & 24 \\
\hline 19 & Nicotinonitrile & $0 \cdot 15$ & $1 \cdot 44$ & $0 \cdot 20$ & 1.92 & 0 & - \\
\hline 23 & Quinolinic acid & $0 \cdot 45$ & $2 \cdot 69$ & $0 \cdot 47$ & $2 \cdot 81$ & $\begin{array}{c}5 \cdot 2 \\
(3 \cdot 7-5 \cdot 9)\end{array}$ & 48 \\
\hline 24 & $\begin{array}{l}\text { 2-Carboxypyridine-3-carboxylic } \\
\text { acid cyclohexylamide }\end{array}$ & $\mathbf{0 \cdot 3 5}$ & $1 \cdot 41$ & $0 \cdot 35$ & $1 \cdot 41$ & 0 & 一 \\
\hline 29 & $\beta$-Picoline & $0 \cdot 45$ & $4 \cdot 85$ & $0 \cdot 48$ & $5 \cdot 16$ & $\begin{array}{c}41 \cdot 3 \\
(35 \cdot 7-53 \cdot 4)\end{array}$ & $48-72$ \\
\hline
\end{tabular}

* See p. 561 .

$\dagger$ The prefix "nicotin-" is used in this paper for the radical compound $\mathrm{CO} \cdot \mathrm{NHC}_{2} \mathrm{H}_{5}$.

CO. Nicotinethylamide, therefore, stands for the 
Table 2. Utilization of nicotinic acid, nicotinamide and related compounds by Tribolium

\begin{tabular}{|c|c|c|c|c|c|c|}
\hline \multirow[b]{2}{*}{ No. } & \multirow[b]{2}{*}{ Name of compound } & \multirow{2}{*}{$\begin{array}{l}\text { Amount } \\
\text { of drug } \\
\text { in diet } \\
(\mu \mathrm{g} . / \mathrm{g} .)\end{array}$} & \multicolumn{2}{|c|}{ Surviving larvae } & \multirow[b]{2}{*}{$\begin{array}{l}\text { No. of } \\
\text { pupae }\end{array}$} & \multirow{2}{*}{$\begin{array}{c}\text { Average } \\
\text { time of } \\
\text { pupation } \\
\text { (days) }\end{array}$} \\
\hline & & & No. & $\begin{array}{c}\text { Size } \\
(\mathrm{mm} .)\end{array}$ & & \\
\hline 1 & Nicotinic acid & $\begin{array}{r}2 \\
4 \\
8 \\
16 \\
32\end{array}$ & $\begin{array}{l}= \\
z \\
=\end{array}$ & $\begin{array}{l}= \\
\overline{-} \\
\overline{-}\end{array}$ & $\begin{array}{l}14 \\
16 \\
20 \\
20 \\
18\end{array}$ & $\begin{array}{l}\mathbf{4 4 \cdot 6} \\
\mathbf{3 7} \cdot \mathbf{4} \\
\mathbf{3 7 \cdot 6} \\
\mathbf{3 5} \cdot 8 \\
\mathbf{3 5} \cdot 4\end{array}$ \\
\hline 2 & Methyl nicotinate & \multicolumn{5}{|c|}{ Same activity as nicotinic acid } \\
\hline $\mathbf{3}$ & Ethyl nicotinate & $\begin{array}{r}8 \\
16 \\
32 \\
64\end{array}$ & $\bar{z}$ & $\bar{z}$ & $\begin{array}{l}19 \\
18 \\
20 \\
18\end{array}$ & $\begin{array}{l}45 \cdot 0 \\
36 \cdot 1 \\
35 \cdot 8 \\
35 \cdot 6\end{array}$ \\
\hline 4 & Nicotinamide & \begin{tabular}{r|r}
2 \\
4 \\
8 \\
16 \\
32
\end{tabular} & $\begin{array}{l}20 \\
= \\
=\end{array}$ & $\begin{array}{l}3-5 \\
= \\
=\end{array}$ & $\begin{array}{r}0 \\
18 \\
17 \\
19 \\
19\end{array}$ & $\begin{array}{c}0 \\
41 \cdot 1 \\
37 \cdot 0 \\
35 \cdot 4 \\
36 \cdot 1\end{array}$ \\
\hline $\mathbf{5}$ & Nicotinethylamide & $\begin{array}{l}100 \\
300 \\
900\end{array}$ & $\frac{19}{-}$ & $\begin{array}{l}3-5 \\
-\end{array}$ & $\begin{array}{r}0 \\
20 \\
15\end{array}$ & $\begin{array}{c}0 \\
49 \cdot 8 \\
35 \cdot 8\end{array}$ \\
\hline 6 & Nicotindiethylamide & $\begin{array}{r}5 \\
25 \\
125 \\
625\end{array}$ & $\begin{array}{r}5 \\
12 \\
16 \\
-\end{array}$ & $\begin{array}{l}2-3 \\
2-3 \\
2-3 \\
-\end{array}$ & $\begin{array}{r}0 \\
0 \\
0 \\
19\end{array}$ & $\begin{array}{c}0 \\
0 \\
0 \\
\mathbf{4 0} \cdot 4\end{array}$ \\
\hline 7 & Nicotinallylamide & $\begin{array}{l}20 \\
40 \\
80\end{array}$ & $\frac{17}{-}$ & $\begin{array}{l}4-5 \\
-\end{array}$ & $\begin{array}{r}0 \\
20 \\
17\end{array}$ & $\begin{array}{c}\mathbf{0} \\
\mathbf{3 9 \cdot 5} \\
\mathbf{3 4 \cdot 3}\end{array}$ \\
\hline 8 & Nicotincyclohexylamide & 1000 & - & - & Few & $>100$ \\
\hline 9 & $\begin{array}{l}\text { Nicotin-(2'-methylcyclohexyl)- } \\
\text { amide }\end{array}$ & 1000 & - & - & Few & $>100$ \\
\hline 11 & $\begin{array}{l}\text { Nicotin-(4'-methylcyclohexyl)- } \\
\text { amide }\end{array}$ & 1000 & - & - & Few & $>100$ \\
\hline 12 & Nicotinphenylamide & $\begin{array}{l}100 \\
300 \\
900\end{array}$ & E & E & $\begin{array}{l}18 \\
19 \\
18\end{array}$ & $\begin{array}{l}\mathbf{3 5 \cdot 5} 5 \\
\mathbf{3 7 \cdot 3} 3 \\
\mathbf{3 8 \cdot 0}\end{array}$ \\
\hline 14 & $\begin{array}{l}\text { Nicotin-(4'-methoxyphenyl)- } \\
\text { amide }\end{array}$ & $\begin{array}{l}20 \\
40 \\
80\end{array}$ & E & 二 & $\begin{array}{l}17 \\
19 \\
13\end{array}$ & $\begin{array}{l}37 \cdot 1 \\
36 \cdot 1 \\
35 \cdot 3\end{array}$ \\
\hline 15 & Nicotinbenzylamide & $\begin{array}{r}100 \\
1000\end{array}$ & 19 & 3-4 & $\begin{array}{r}0 \\
17\end{array}$ & $\begin{array}{c}0 \\
\mathbf{3 6} \cdot 7\end{array}$ \\
\hline 18 & Nicotinamide methochloride & $\begin{array}{r}100 \\
500 \\
2500\end{array}$ & & $\begin{array}{l}\text { th } \\
\text { th } \\
-\end{array}$ & $\begin{array}{c}0 \\
0 \\
\text { Few }\end{array}$ & $\begin{aligned} & 0 \\
& 0 \\
> & 100\end{aligned}$ \\
\hline 19 & Nicotinonitrile & $\begin{array}{r}100 \\
1000\end{array}$ & 二 & 二 & $\begin{array}{l}\text { Few } \\
\text { Few }\end{array}$ & $\begin{array}{l}>100 \\
>100\end{array}$ \\
\hline 23 & Quinolinic acid & $\begin{array}{r}20 \\
100 \\
500 \\
2500\end{array}$ & ${ }_{20}^{\mathrm{N}} \mathrm{N}$ & 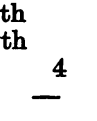 & $\begin{array}{r}0 \\
0 \\
0 \\
17\end{array}$ & $\begin{array}{c}0 \\
0 \\
0 \\
\mathbf{3 9 \cdot 0}\end{array}$ \\
\hline 29 & $\beta$-Picoline & $\begin{array}{r}250 \\
2500 \\
5000 \\
10000 \\
20000\end{array}$ & $\begin{array}{l}17 \\
=\end{array}$ & $\begin{array}{l}4 \\
= \\
-\end{array}$ & $\begin{array}{r}0 \\
16 \\
19 \\
15 \\
18\end{array}$ & $\begin{array}{r}0 \\
60 \\
49 \\
44 \\
40\end{array}$ \\
\hline
\end{tabular}


vened from paralysis of the respiratory centre. Some of the compounds (nos. 1, 7 and 13) produced a peripheral vasodilatation, another (no. 29) a distinct hypersensitivity to touch of tail and legs. Generally, death occurred within $2 \mathrm{hr}$. of the injection of the compound. If this critical period was overcome there was generally complete recovery. In a few cases, however, an apparent recovery was followed after 24-48 hr. by collapse and death from respiratory paralysis. In nearly all the compounds, the LD50 was very well defined and frequently one quarter or one half of the lethal dose had no recognizable effect on the animals.

Nicotinamide methochloride formation by animal tissues in vitro. The experiments carried out with tissue slices to identify the organ responsible for the breakdown of the drug to nicotinamide or nicotinic acid gave negative results. Nicotinamide methochloride was produced only, when either nicotinamide was shaken with liver slices, or nicotinic acid with liver and kidney, or liver and brain slices.

\section{The utilization of various pyridine derivatives by insects}

The following compounds produced neither growth of larvae nor pupation in doses up to $1 \mathrm{mg}$./g. dried food: nicotin-(3'-methylcyclohexyl)-amide, nicotindiphenylamide, nicotindibenzylamide, trigonelline hydrochloride (prepared according to Hantzsch, 1886), 6-hydroxynicotinic acid (Light and Co.), picolinic acid (Roche), pyridine-4-carboxylic acid (Light and Co.), 2-carboxypyridine-3-carboxylic acid cyclohexylamide (Bayer), pyridine-3:4-dicarboxylic acid (Light and Co.), pyridine-2:5-dicarboxylic acid (Roche), pyridine, $\alpha$-picoline (B.D.H.) and $\gamma$-picoline (Light and Co.).

There was no growth at all when the larvae were fed the basal diet. Usually the minimum concentration of nicotinic acid in the diet required for optimal growth was $8 \mu \mathrm{g} . / \mathrm{g}$., but on one occasion optimal growth was obtained with $4 \mu \mathrm{g}$./g. In all experiments the efficiency of methyl nicotinate equalled that of nicotinic acid, whilst the ethyl ester had about one quarter and nicotinamide about one half of the activity of nicotinic acid.

Nicotinamide methochloride content of Tenebrio larvae. An extract obtained by the addition of dilute $\mathrm{HCl}(450 \mathrm{ml}$.) to Tenebrio larvae $(60 \mathrm{~g}$.) contained 7.4 $\mu \mathrm{g}$. nicotinamide methochloride $/ 60 \mathrm{~g}$. wet or $20 \mathrm{~g}$. dry larvae. The alkaline isobutanol solutions of the Coulson, Ellinger \& Holden test gave a greenish fluorescence with $12 \mathrm{~N}-\mathrm{NaOH}$ which faded on standing at room temperature, turning yellow. With dilute ferricyanide a deep violet fluorescence developed and the addition of alkali and acetone produced a yellow colour with green fluorescence. This proved the identity of the fluorescent substance with ' $F_{2}$ '.

\section{The utilization of various pyridine derivatives} by bacteria

Compounds no. (7) nicotinallylamide (Bayer), (8) nicotincyclohexylamide (Bayer), (9) nicotin(2'-methylcyclohexyl)-amide (Bayer), (10) nicotin(3'-methylcyclohexyl)-amide (Bayer), (11) nicotin(4'-methylcyclohexyl)-amide (Bayer), (12) nicotinphenylamide (Bayer), 13) nicotindiphenylamide (Bayer), (14) nicotin-(4'-methoxyphenyl)-amide (Bayer), (15) nicotinbenzylamide (Bayer), (16) nicotindibenzylamide (Bayer), (17) trigonelline hydrochloride (Hantzsch, 1886), (18) nicotinamide methochloride (Karrer, Schwarzenbach, Benz \& Solmssen, 1936) (Roche) (19) nicotinonitrile (Dr J. Walker, National Institute for Medical Research) and (24) 2-carboxypyridine-3-carboxylic acid cyclohexylamide (Bayer) were tested. They produced no growth, but a small amount of acid, generally less than 1/100th of that produced with nicotinic acid by Lactobacillus arabinosus and neither growth occurred nor acid was produced by any of the other bacteria tested when the various drugs were applied in doses up to 0.03 or $0.05 \mu \mathrm{g} . / \mathrm{ml}$.

The effects of nicotinic acid and nicotinamide on the growth of Proteus vulgaris 5887, Shigella dysenteriae (Shiga) 4837 and Flexner 4832 were so small that tests of the related compounds on these bacteria were abandoned. No increased growth or acid formation resulted from addition of nicotinamide methochloride to cultures of Esch . coli in doses of 0.0001$10 \mu \mathrm{g} . / \mathrm{ml}$., but a distinct inhibition was observed which gradually increased with rising concentration.

The amounts of nicotinamide methochloride formed when Proteus vulgaris 3156 was incubated with nicotinamide or nicotinic acid in BartonWright medium for $48 \mathrm{hr}$. are shown in Table 4 . No nicotinamide methochloride was found in culturefree medium after $48 \mathrm{hr}$. incubation or in the unincubated inoculum. Thus no nicotinamide metho. chloride was released from intact cells into the medium. More nicotinamide methochloride was formed from nicotinamide than from nicotinic acid and an increase in concentration of the substrate from $0 \cdot 1 \mu \mathrm{g} . / \mathrm{ml}$. to $1 \cdot 0 \mu \mathrm{g} . / \mathrm{ml}$ : did not significantly increase the formation of nicotinamide methochloride. Nicotinamide methochloride formation from nicotinic acid and nicotinamide was greater under anaerobic than under aerobic conditions. The tests of the fluorescent alkaline isobutanol solutions with $12 \mathrm{~N}-\mathrm{NaOH}$, ferricyanide and alkaline acetone indicated the presence of ' $F_{2}$ '.

\section{DISCUSSION}

Toxicity. The general pharmacological effects on mice and rats, namely excitement and narcosis of the central nervous system and particularly of the 
Table 3. Utilization of nicotinic acid, nicotinamide and related compounds by various bacteria

\begin{tabular}{|c|c|c|c|c|c|c|c|c|c|}
\hline & $\begin{array}{l}\text { Name of } \\
\text { compound }\end{array}$ & $\begin{array}{c}\text { Drug } \\
\text { content } \\
\text { of medium } \\
(\mu \mathrm{g} . / \mathrm{ml} .)\end{array}$ & $\begin{array}{c}\text { Growth } \\
\text { (arbitrary } \\
\text { units) }\end{array}$ & $\begin{array}{c}\text { Acid } \\
\text { formed } \\
(\mathrm{ml} .0 \cdot 1 \mathrm{~N}- \\
\mathrm{NaOH})\end{array}$ & $\begin{array}{c}\text { Efficiency } \\
\text { compared } \\
\text { with } \\
\text { that of } \\
\text { nicotinic } \\
\text { acid }\end{array}$ & $\begin{array}{c}\text { Drug } \\
\text { content } \\
\text { of medium } \\
(\mu \mathrm{g} . / \mathrm{ml} .)\end{array}$ & $\begin{array}{c}\text { Growth } \\
\text { (arbitrary } \\
\text { units) }\end{array}$ & $\begin{array}{c}\text { Acid } \\
\text { formed } \\
\text { (ml. 0.1 N- } \\
\mathrm{NaOH} \text { - }\end{array}$ & $\begin{array}{l}\text { Efficiency } \\
\text { compared } \\
\text { with } \\
\text { that of } \\
\text { nicotinic } \\
\text { acid }\end{array}$ \\
\hline No. & & \multicolumn{4}{|c|}{ Lactobacillus arabinosus } & \multicolumn{4}{|c|}{ Proteus vulgaris 401} \\
\hline 1 & Nicotinic acid & $\begin{array}{l}0.005 \\
0.01 \\
0.02 \\
0.04 \\
0.08 \\
0.12\end{array}$ & $\begin{array}{c}+ \\
++ \\
++ \\
5+ \\
6+ \\
8+\end{array}$ & $\left.\begin{array}{l}0 \cdot 67 \\
1 \cdot 37 \\
2 \cdot 69 \\
4 \cdot 46 \\
4.91 \\
5.99\end{array}\right\}$ & 1 & $\begin{array}{l}0.0025 \\
0.005 \\
0.01 \\
0.02\end{array}$ & $\begin{array}{c}+ \\
++ \\
+4 \\
+++\end{array}$ & $\left.\begin{array}{l}0.16 \\
0.21 \\
0.26 \\
0.31\end{array}\right\}$ & 1 \\
\hline 4 & Nicotinamide & $\begin{array}{l}0.005 \\
0 \cdot 01 \\
0 \cdot 02 \\
0 \cdot 04 \\
0 \cdot 08 \\
0 \cdot 12\end{array}$ & $\begin{array}{c}+ \\
++ \\
+++ \\
5+ \\
6+ \\
8+\end{array}$ & $\begin{array}{l}0 \cdot 70 \\
1 \cdot 37 \\
2 \cdot 73 \\
\mathbf{3} \cdot 86 \\
\mathbf{4} \cdot 37 \\
\mathbf{5} \cdot 48\end{array}$ & $\begin{array}{l}1 \\
0 \cdot 86 \\
0 \cdot 89 \\
0.92\end{array}$ & $\begin{array}{l}0.0025 \\
0.005 \\
0.01 \\
0.02\end{array}$ & $\begin{array}{l}+ \\
++ \\
++ \\
++\end{array}$ & $\left.\begin{array}{l}0 \cdot 15 \\
0 \cdot 19 \\
0 \cdot 25 \\
0 \cdot 31\end{array}\right\}$ & 1 \\
\hline 5 & $\begin{array}{l}\text { Nicotin- } \\
\text { ethylamide }\end{array}$ & $\begin{array}{l}0.08 \\
0 \cdot 12 \\
0 \cdot 20\end{array}$ & $\begin{array}{l}0 \\
0 \\
0\end{array}$ & $\left.\begin{array}{l}0.045 \\
0.065 \\
0.155\end{array}\right\}$ & 0.01 & $\begin{array}{l}0.02 \\
0.03\end{array}$ & \pm & $\left.\begin{array}{l}0.07 \\
0.09\end{array}\right\}$ & $0 \cdot 2$ \\
\hline 6 & $\begin{array}{l}\text { Nicotin- } \\
\text { diethylamide }\end{array}$ & $\begin{array}{l}0.08 \\
0 \cdot 12 \\
0 \cdot 20\end{array}$ & $\begin{array}{l}0 \\
0 \\
0\end{array}$ & $\left.\begin{array}{l}0.045 \\
0.045 \\
0.090\end{array}\right\}$ & $<0.01$ & $\begin{array}{l}0.02 \\
0.03\end{array}$ & $\begin{array}{l}0 \\
0\end{array}$ & $\begin{array}{l}0 \\
0\end{array}$ & 0 \\
\hline 23 & Quinolinic acid & $\begin{array}{l}0.08 \\
0.12 \\
0.20\end{array}$ & $\begin{array}{l} \pm \\
\pm \\
+\end{array}$ & $\left.\begin{array}{l}0 \cdot 14 \\
0 \cdot 19 \\
0 \cdot 33\end{array}\right\}$ & c. 0.012 & $\begin{array}{l}0.02 \\
0.03\end{array}$ & $\begin{array}{l}+ \\
+\end{array}$ & $\left.\begin{array}{l}0.06 \\
0.07\end{array}\right\}$ & $0 \cdot 2$ \\
\hline \multirow[t]{2}{*}{29} & $\beta$-Picoline & $\begin{array}{l}0.08 \\
0 \cdot 12 \\
0 \cdot 20\end{array}$ & $\begin{array}{l} \pm \\
\pm \\
+\end{array}$ & $\left.\begin{array}{l}0.03 \\
0.11 \\
0.24\end{array}\right\}$ & c. 0.008 & $\begin{array}{l}0.02 \\
0.03\end{array}$ & + & $\left.\begin{array}{l}0.06 \\
0.07\end{array}\right\}$ & $0 \cdot 2$ \\
\hline & & \multicolumn{4}{|c|}{ Proteus X 13} & \multicolumn{4}{|c|}{ Proteus morganii } \\
\hline 1 & Nicotinic acid & $\begin{array}{l}0.0025 \\
0.005 \\
0.01 \\
0.02\end{array}$ & $\begin{array}{c}+++ \\
++++ \\
6+ \\
8+\end{array}$ & $\left.\begin{array}{l}0.18 \\
0.31 \\
0.41 \\
0.52\end{array}\right\}$ & 1 & $\begin{array}{l}0.0025 \\
0.005 \\
0.01 \\
0.02 \\
0.04 \\
0.06\end{array}$ & $\begin{array}{c}+ \\
++ \\
+++ \\
++++ \\
6+ \\
8+\end{array}$ & 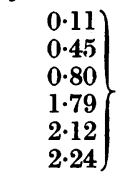 & 1 \\
\hline 4 & Nicotinamide & $\begin{array}{l}0.0025 \\
0.005 \\
0.01 \\
0.02\end{array}$ & $\begin{array}{c}++ \\
++++ \\
6+ \\
8+\end{array}$ & $\begin{array}{l}0 \cdot 11 \\
0 \cdot 23 \\
0 \cdot 39 \\
0 \cdot 45\end{array}$ & $\left.\begin{array}{l}0.67 \\
0.74 \\
0.95 \\
0.87\end{array}\right\} 0 \cdot 79$ & $\begin{array}{l}0.0025 \\
0.005 \\
0.01 \\
0.02 \\
0.04 \\
0.06\end{array}$ & $\begin{array}{c}+ \\
++ \\
+++ \\
++++ \\
6+ \\
8+\end{array}$ & $\left.\begin{array}{l}0 \cdot 15 \\
0 \cdot 38 \\
0 \cdot 79 \\
1 \cdot 75 \\
2 \cdot 23 \\
2 \cdot 26\end{array}\right\}$ & 1 \\
\hline 5 & $\begin{array}{l}\text { Nicotin- } \\
\text { ethylamide }\end{array}$ & $\begin{array}{l}0 \cdot 05 \\
0 \cdot 1\end{array}$ & $\stackrel{ \pm}{+}$ & $\left.\begin{array}{l}0.05 \\
0.09\end{array}\right\}$ & 0.02 & $0 \cdot 05$ & 0 & 0 & $\mathbf{0}$ \\
\hline 6 & $\begin{array}{l}\text { Nicotin- } \\
\text { diethylamide }\end{array}$ & $\begin{array}{l}0.05 \\
0 \cdot 1\end{array}$ & $\begin{array}{l} \pm \\
\pm\end{array}$ & $\begin{array}{l}0.05 \\
0\end{array}$ & $\begin{array}{l}0.02 \\
0\end{array}$ & 0.05 & 0 & 0 & 0 \\
\hline 23 & Quinolinic acid & $\begin{array}{l}0.02 \\
0.03\end{array}$ & + & $\left.\begin{array}{l}0.17 \\
0.21\end{array}\right\}$ & $0 \cdot 12$ & $\begin{array}{l}0.02 \\
0.03\end{array}$ & + & $\left.\begin{array}{l}0.40 \\
0.41\end{array}\right\}$ & $0 \cdot 15-0 \cdot 25$ \\
\hline 29 & $\beta$-Picoline & $\begin{array}{l}0.02 \\
0.03\end{array}$ & + & $\left.\begin{array}{l}0.15 \\
0.20\end{array}\right\}$ & $0 \cdot 1$ & $\begin{array}{l}0.02 \\
0.03\end{array}$ & + & $\left.\begin{array}{l}0.37 \\
0.40\end{array}\right\}$ & $0 \cdot 12-0 \cdot 16$ \\
\hline
\end{tabular}

Table 4. Nicotinamide methochloride formation from nicotinamide and nicotinic acid by Proteus vulgaris 3156 after aerobic and anaerobic incubation at $37^{\circ}$ for $48 \mathrm{hr}$.

Nicotinamide methochloride formed $(\mu \mathrm{g} . / 10 \mathrm{ml}$.) on

$\begin{array}{cc} & \begin{array}{c}\text { Concentration } \\ \text { of substrate } \\ (\mu \mathrm{g} . / \mathrm{ml} .)\end{array} \\ \text { Substrate } & 0 \cdot 1 \\ \text { Nicotinamide } & 1 \cdot 0 \\ \text { Nicotinic acid } & 0 \cdot 1 \\ & 1 \cdot 0\end{array}$

\begin{tabular}{|c|c|}
\hline \multicolumn{2}{|c|}{ (a) Aerobic incubation } \\
\hline n medium & - In organisms \\
\hline $\begin{array}{l}0 \\
0\end{array}$ & $\begin{array}{l}1 \cdot 71 \\
1 \cdot 71\end{array}$ \\
\hline $\begin{array}{l}0 \\
0\end{array}$ & $\begin{array}{l}0.62 \\
0.75\end{array}$ \\
\hline
\end{tabular}

$\overbrace{\text { In medium }}^{\text {(b) Anaerobic incubation }}$


respiratory centre, seem to be quite separate from the metabolic action of nicotinamide. They occur immediately after the injection and disappear after a few minutes, when sublethal doses are given. It is almost certain that in consequence of this action on the central nervous system, no single dose can be administered which can seriously diminish the methyl donors of the body. The toxicity observed in these experiments is similar to that reported by Chen et al. (1938), Unna (1939) and Brazda \& Coulson (1946) for nicotinic acid, nicotinamide, nikethamide, and trigonelline; but there is a discrepancy as to the relative toxicity of nicotinamide and its methochloride. Brazda \& Coulson found the latter to be less toxic than nicotinamide (by $33 \%$ ), while our results indicate that nicotinamide methochloride is twice as toxic as nicotinamide itself; this finding is not in accordance with the generally accepted idea that this methylation is a detoxication (Perlzweig \& Huff, 1945). The toxicity of each of the compounds examined is almost identical for mice and rats with the exception of nicotinamide methochloride which is about twice as toxic for the mouse as for the rat. The toxicity of the various compounds examined rises continuously from the fairly hydrotropic nicotinic acid, trigonelline, nicotinamide and nicotinamide methochloride by more than 100 times to the lipotropic nicotin-diphenyl- and -dibenzyl-amides. Since the main point of attack is presumably on the lipids of the central nervous system, the increased toxicity of the phenyl and benzyl compounds might be related to the partition coefficients between aqueous and lipid phases. This factor is likely to favour concentration of the more toxic compounds in lipids.

Conversion to nicotinic acid in mammals. The ability to increase the formation and elimination of nicotinamide methochloride is based on the intermediary formation of nicotinamide. Antiblacktongue and antipellagra activities are certainly a property of nicotinamide. Therefore one may attribute antiblack-tongue and antipellagra activities to those compounds which give rise to an intermediary formation of nicotinamide. There is general agreement among the various investigators mentioned in the introduction, that nicotinamide as well as nicotinic acid, its salts and esters and nicotinuric acid possess antiblack-tongue and antipellagra activities. Our experiments have shown a nicotinamide methochloride response to all of these substances which were examined. If the activities against black-tongue and against pellagra respectively are identical, then the results with regard to quinolinic acid and nicotinamide methochloride are difficult to explain. Woolley et al. (1938) did not find any antiblack-tongue activity with quinolinic acid which seemed to have a marked antipellagra effect in the experiments of Vilter \& Spies (1939). Our experiments are in agreement with the findings of the latter workers. Nicotinamide methochloride was found to be inactive against canine black-tongue by Woolley et al. (1938), and later by Teply et al. (1945), but was claimed to be active by Najjar et al. (1944). The experiments of Elvehjem and co-workers are, however, not fully conclusive because the compound was given orally and with this route of administration only a small proportion is absorbed from the intestine (Ellinger \& Coulson, 1944 ; Ellinger, 1947). Najjar's work needs confirmation and our results are not able to decide the matter in question. $\beta$-Picoline has antiblacktongue activity, but to a much lower degree than the other compounds examined and found active by Woolley et al. (1938). In our experiments the response to $\beta$-picoline was greater than to all other compounds tested except nicotinamide methochloride. It is difficult to explain this fact in the present state of our knowledge of the mechanism of the intermediary process. Unfortunately the method used by Perlzweig, Bernheim \& Bernheim (1943) and Ellinger (1946) to elucidate the mechanism of methylation of nicotinamide and of the formation of nicotinamide from nicotinic acid yielded no results. We do not know definitely, whether the substituted nicotinamide derivatives are broken down to nicotinic acid or nicotinamide. However, the quantitative nicotinamide methochloride response to the various compounds yields some information. The response by the rat to extradietary doses is $22.7 \%$ to nicotinamide and $11.8 \%$ to nicotinic acid, similar to the values found in man by Ellinger \& Coulson (1944). A breakdown to nicotinic acid and intermediary formation of nicotinamide and nicotinamide methochloride would be limited by the nicotinic acid response to values below $11.8 \%$; the alkyl derivatives, mono- and di-ethyl- and monoallylamides show, however, responses of $17 \cdot 2,16 \cdot 8$ and $15 \cdot 7 \%$ respectively, which are intermediate between those to nicotinamide and nicotinic acid. For these three compounds dealkylation to the amide is most probable; that such a reaction can occur follows from the observations of Elson, Goulden \& Warren (1946) who found that dimethylaniline is partly eliminated as $p$-aminophenylsulphonic acid by the rat.

The monoaryl derivatives of nicotinamide (nos. 12, 14 and 15) too produced an increase of nicotinamide methochloride elimination, the response being about $6 \%$. This low value might be due to the fact that these monoaryl derivatives break down to nicotinic acid and not to nicotinamide. The diaryl derivatives (nos. 13 and 16) and the cyclohexyl derivatives (nos. 8, 9, 10, 11 and 24) and nicotinonitrile (no. 19) do not appear in the urine as nicotinamide methochloride, and it is concluded that their breakdown does not lead to either nicotinamide or nicotinic acid. Quinolinic acid is decarboxylated in the 2-position and about $5 \%$ of it appears in the 
urine as nicotinamide methochloride, a response similar to that of themonoaryl derivatives. From trigonelline no nicotinamide methochloride is formed. On the average $62.7 \%$ of the administered nicotin. amide methochloride is eliminated in the urine; similar values were observed in man after parenteral ingestion (Ellinger \& Coulson, 1944; Perlzweig \& Huff, 1945). The remainder is probably eliminated with the bile and destroyed by the intestinal flora (Ellinger, 1947). There remains only $\beta$-picoline (no. 29) which appears in the urine as nicotinamide methochloride to the extent of $35 \cdot 7-53.4 \%$, a response much higher than with nicotinamide. This, together with its low antiblack-tongue and antipellagra activity, can only be understood, if it is assumed that its metabolic transformation into nicotinamide methochloride occurs in such a manner that nicotinamide is not involved as an intermediate; it may be suggested that methylation in the 1-position precedes oxidation of the 3-methyl group.

Conversion to nicotinic acid by insects. While in the rat, besides nicotinic acid and nicotinamide, the alkyl and monoaryl derivatives were comparatively well utilized, Tribolium was found to be more exacting. Nicotinic acid, its esters, and nicotinamide were well utilized, but most of the other compounds tested had little activity. The oniy exceptions were nicotinallylamide (no. 7), nicotin(4'-methoxyphenyl)-amide (no. 14) and nicotinphenylamide (no. 12), whose activity was about $10-20 \%$ of that of nicotinic acid. A definite, but much lower activity was shown by nicotinmonoand -di-ethylamides (nos. 5 and 6), nicotinbenzylamide (no. 15), quinolinic acid (no. 23) and $\beta$-picoline (no. 29). This activity might be due to a slight contamination of about $2 \%$ with nicotinamide or nicotinic acid from which all the compounds tested except $\beta$-picoline and quinolinic acid are made. This is unlikely since most of these substances showed no activity in bacteria. It appears therefore, that all these substances are utilized by Tribolium, if only to a small extent.

Utilization of the various pyridine derivatives by bacteria. In most of the bacteria examined nicotinamide and nicotinic acid were utilized almost equally well except for Proteus X 13 which utilized the former by about $20 \%$ less well than the latter. All the other compounds were utilized, if at all, to a much lower degree. Lactobacillus arabinosus utilized only nicotinic acid and its amide, in agreement with the results of Elvehjem \& Teply (1943), quinolinic acid, $\beta$-picoline and nicotinonitrile. The small effect of other derivatives might be explained by contamination with one of the two active compounds. In Proteus vulgaris 401 and 3156, nicotinethylamide (no. 5) quinolinic acid (no. 23) and $\beta$-picoline (no. 29) showed an activity of about $20 \%$ of that of nicotinic acid. In Proteus $\mathrm{X} 13$ these compounds and nicotindiethylamide (no. 6) showed an even smaller activity which, in the case of nicotinmono- and -di-ethylamides, can be attributed to a slight contamination with nicotinamide or nicotinic acid. The slight effect of these compounds is in general agreement with the findings of Lwoff \& Querido (1939). The positive results reported by the French workers for nicotinonitrile may be due to impurities. Shigella sonnei utilized, of all compounds tested, only nicotinic acid and its amide and, to a much smaller extent, quinolinic acid and $\beta$ picoline. This confirms the findings by Dorfman et al. (1939) also with regard to nicotinonitrile. The positive effect found by these workers for nicotindiethylamide can be attributed to contamination with nicotinic acid or amide. The findings of Najjar et al. (1943) that nicotinamide methochloride promotes the growth of Esch. coli could not be confirmed. Najjar's results may also have been caused by heavy contamination with nicotinamide or nicotinic acid. The antiblack-tongue effect of nicotinamide methochloride (Najjar et al. 1944) can be explained in a similar manner. Nicotinic acid and nicotinamide promote growth with Esch. coli (Ellinger \& Abdel Kader, 1947).

General conclusion. Comparing the utilization by rat, insect and bacterium of the different compounds tested one realizes that different mechanisms play a role in the transformation of the various compounds into either nicotinamide or nicotinic acid. The rat is able to convert most of the compounds, all alkyl and monoaryl derivatives of nicotinamide and quinolinic acid and $\beta$-picoline, into either nicotinamide or nicotinic acid. The mechanisms involved consist in either dealkylation, deamination, decarboxylation or oxidation. The two latter processes seem to occur in insects and in those bacteria tested, whilst dealkylation and deamination are much more restricted in insects and almost entirely absent in bacteria.

\section{SUMMARY}

1. The general pharmacological action and toxicity of a number of substituted nicotinamide derivatives and of a few other related compounds have been examined in the mouse and rat. Their conversion of these compounds into nicotinamide methochloride by the rat has also been tested. Relations between physico-chemical properties and toxicity and between chemical constitution and metabolic transformation into nicotinamide methochloride have been discussed.

2. This utilization by the rat has been compared with that by insects and bacteria. It was found that all those compounds which could be utilized by bacteria were also utilized by the higher species, similarly all the substances which were utilized by insects were utilized by rats, but not vice versa. 
3. In addition to nicotinamide and nicotinic acid, rats utilized all alkyl and monoaryl nicotinamides, quinolinic acid and $\beta$-picoline, but not dialkyl or cyclohexyl nicotinamides or nicotinonitrile. Insects utilized nicotinamide and nicotinic acid and their esters, and less well the mono-and di-alkyland monoaryl nicotinamides, and still less quinolinic acid and $\beta$-picoline. Of the bacteria examined, all utilized nicotinic acid and nicotinamide, quinolinic acid and $\beta$-picoline, but only Proteus vulgaris and Proteus X13 utilized the monoethylamide; the latter also utilized the diethylamide and Lactobacillus arabinosus also nicotinonitrile.

4. Nicotinamide methochloride was found to be present in Tenebrio larvae and was formed by Proteus vulgaris from nicotinic acid and nicotinamide.
The authors are deeply indebted to the late $\mathrm{Dr} H$. Schütze for advice with the bacteriological work; they wish to thank Dr A. Emmanuelowa for isolation of Esch. coli from faeces and for maintaining the various cultures used, Miss M. Blewett, Miss J. Vaughan Morgan and Mr W. Wolff for technical assistance, Sir P. Hartley for supply of aneurin, riboflavin, pyridoxin, calcium pantothenate and biotin, Dr T. F. Macrae for the supply of vitamin-free casein hydrolysate, cystine, adenine, guanine, xanthine, uracil, $d l$-tryptophan and of a strain of Lactobacillus arabinosus, Dr A. Lwoff, Paris for a culture of Proteus X 13, Dr J. Walker for a sample of nicotinonitrile, Bayer Products Ltd. for the supply of the substituted nicotinamide derivatives, and Roche Products Ltd., for nicotinamide and nicotinic acid. One of the authors (G. F.) is indebted to the Medical Research Council for a grant for the study of insect nutrition, and the other (P.E.) wishes to acknowledge a grant from the Ella Sachs Plotz Foundation, Boston, Mass., for technical assistance.

\section{REFERENCES}

Ackermann, D. (1913). Z. Biol. 59, 17.

Barton-Wright, E. C. (1944). Biochem. J. 38, 314.

Bills, C. E., McDonald, F. G. \& Spies, T. D. (1939). South. Med. J. 32, 793.

Blewett, M. \& Fraenkel, G. (1944). Proc. Roy. Soc. B, 132, 212.

Brazda, F. G. \& Coulson, R. A. (1946). Proc. Soc. exp. Biol., N.Y., 62, 19.

Chen, K. K., Rose, C. L. \& Robbins, E. B. (1938). Proc. Soc. exp. Biol., N.Y., 38, 241.

Coulson, R. A., Ellinger, P. \& Holden, M. (1944). Biochem. $J .38,150$.

Dann, W. J. \& Handler, P. (1941). Proc. Soc. exp. Biol., N.Y., 48, 355.

Dorfman, A., Koser, S. A., Reames, H. R., Swingle, K. F. \& Saunders, F. (1939). J. infect. Dis. 65, 163.

Ellinger, P. (1946). Biochem. J. 40, xxxi.

Ellinger, P. (1947). Biochem. J. 41, 308.

Ellinger, P. \& Abdel Kader, M. M. (1947). Unpublished results.

Ellinger, P. \& Coulson, R. A. (1944). Biochem. J. 38, 265.

Elson, L. A., Goulden, F. \& Warren, F. L. (1946). Biochem. $J .40$, xxix.

Elvehjem, C. A. \& Teply, L. J. (1943). Chem. Rev. 33, 185.

v. Euler, H., Högberg, B., Karrer, P., Salomon, H. \& Ruckstuhl, H. (1944). Helv. chim. Acta, 27, 382.

Fildes, P. (1938). Brit. J. exp. Path. 19, 239.

Fraenkel, G. \& Blewett, M. (1943a). J. exp. Biol. 20, 28.

Fraenkel, G. \& Blewett, M. (1943b). Biochem. J. 37, 686.

Fraenkel, G. \& Blewett, M. (1946a). J. exp. Biol. 22, 156.

Fraenkel, G. \& Blewett, M. (1946b). J. exp. Biol. 22, 162.

Handler, P. \& Perlzweig, W. A. (1945). Ann. Rev. Biochem. 14, 628 .

Hantzsch, A. (1886). Ber. dtsch. chem. Ges. 19, 31.

Karrer, P., Schwarzenboch, G., Benz, F. \& Solmssen, U. (1936). Helv. chim. Acta, 19, 826.

Krebs, H. A. \& Henseleit, K. (1932). Hoppe-Seyl. Z. 210, 83.

Landy, M. (1938). Proc. Soc. exp. Biol., N.Y., 38, 504.

Lwoff, A. (1938). Ann. Inst. Pasteur, 61, 580.

Lwoff, A. \& Querido, A. (1939). C.R. Soc. Biol., Paris, $130,1569$.
McCollum, E. V., Simmonds, N. \& Pitz, W. (1917). J. biol. Chem. 29, 521.

Najjar, V. A., Hammond, M. M., English, M. A., Wooden, M. B. \& Deal, C. C. (1944). Johns Hopk. Hosp. Bull. 74, 406.

Najjar, V. A. \& Holt, jr. L. E. (1941). Proc. Soc. exp. Biol., N.Y., 48, 413.

Najjar, V. A., Scott, D. B. M. \& Holt, jr. L. E. (1943). Science, 97, 537.

Pelczar, jr. M. J. \& Porter, J. R. (1940). J. Bact. 39, 429.

Perlzweig, W. A., Bernheim, M. L. C. \& Bernheim, F. (1943). J. biol. Chem. 150, 401.

Perlzweig, W. A. \& Huff, J. W. (1945). J. biol. Chem. 161, 417.

Rubinshtein, D. L. \& Shekun, L. A. (1941). Bull. biol. med. exp. 8, 190.

Smith, D. T., Margolis, G. \& Margolis, L. H. (1940). J. Pharmacol. 68, 458.

Spies, T. D., Bean, W. B. \& Stone, R. E. (1938). J. Amer. med. Ass. 111, 584.

Spies, T. D., Grant, H. M. \& Huff, N. E. (1938). South. Med. J. 31, 901.

Strong, F. M., Madden, R. J. \& Elvehjem, C. A. (1938). J. Amer. chem. Soc. 60, 2564.

SubbaRow, Y. \& Dann, W. J. (1938). J. Amer. chem. Soc. 60, 2565 .

SubbaRow, Y., Dann, W. J. \& Meilman, E. (1938). J. Amer. chem. Soc. 60, 1510.

SubbaRow, Y. \& Trager, W. (1940). J. gen. Physiol. 23, 561.

Tatum, E. L. (1939). Proc. nat. Acad. Sci., Wash., 25, 490.

Tatum, E. L. (1941). Proc. nat. Acad. Sci., Wash., 27, 193.

Teply, L. J., Krehl, W. A. \& Elvehjem, C. A. (1945). Proc. Soc. exp. Biol., N.Y., 58, 169.

Unna, K. (1939). J. Pharmacol. 65, 95.

Vilter, S. P., Bean, W. B. \& Spies, T. D. (1938). South. Med. J. 31, 1163 .

Vilter, S. P. \& Spies, T. D. (1939). Lancet, 2, 423.

Waisman, H. A., Mickelson, O., McKibbin, J. M. \& Elvehjem, C. A. (1940). J. Nutrit. 19, 483.

Woolley, D. W., Strong, F. M., Madden, R. J. \& Elvehjem, C. A. (1938). J. biol. Chem. 124, 715 . 